|| Print ISSN: 2589-7837 || Online ISSN: 2581-3935 ||

International Journal of Medical Science and Diagnosis Research (IJMSDR)

Available Online at www.ijmsdr.com

NLM (National Library of Medicine ID: 101738824)

\title{
Polyphenols in Matily Herbal \& Spices Boosts Antibodies in an Elderly Following COVID 19 Infections - A Case Study
}

\section{John Thottukadavil Eapen}

\section{MEEISATCODE, Phoenix hospital, Masoli Road, Dahanu Road, Palghar Dist. Maharashtra.}

\section{Conflicts of Interest: Nil}

Corresponding author: John Thottukadavil Eapen

DOI: https://doi.org/10.32553/ijmsdr.v6i1.894

\section{Abstract:}

An elderly patient had COVID-19 infection in August 2020 and started the home remedies treatment for the first 18 hours, followed by Azithromycin $250 \mathrm{mg}$ for 6 days. The patient revered well, and the infection was confirmed by antibodies in the patient's serum. Later on, the patient was on Matily Herbal Drink and Matily Herbal \& Spices Mix to avoid complications connected with COVID-19 re-infection. After completing 12 months of post COVID-19 infection, the antibodies were assessed to find the status. It was found to be increased in qualitative assessment. The quantitative assessment of antibodies showed a much higher value compared with individuals who had both the dose of vaccines and tested the blood after two weeks since the second dose of vaccine. We suggest that the increased antibodies could be because of the bioavailability of polyphenols present in the Matily Herbal Drink and Matily Herbal \& Spices Mix.

Polyphenols inactivate COVID-19 virus and this may have helped the body to increase its antibody production. The bioavailability of polyphenols depends on various factors, including acidulants in the diet. Based on the present studies, we suggest India should have her own strategies to increase antibodies in the population instead of just following the norms laid by International Agencies for the booster dose of vaccine

Keywords: COVID-19, Matily Herbal Drink, Matily Herbal, Spices Mix

\section{Introduction:}

COVID-19 (SARS-CoV-2), known as coronavirus, is a pandemic and a threat to humans of the World over [1]. It caused deaths to many and, as a measure to prevent the spread of virus, frequent lockdowns were implemented in all countries, leading to huge economic losses to all [2]. A brief review of the disease and the treatment status is discussed elsewhere [3]. The virus causes micro and macro vascular clotting in the infected patients that leads to further complications $[4,5]$ or infections like pneumonia [6]. Administration of aspirin to the COVID-19 patients showed better recovery $[7,8,9,10]$. Aspirin is derived from salicylates present in plants [11, 12]. Certain Indian herbs and spices used in Indian cooking are rich in salicylates $[13,14]$ and we proposed that salicylates in Indian diet, open ventilation and early treatment of disease after detection of symptoms may have contributed to the survival of COVID-19 patients in India, though the incidence of disease was high [3].

Recently, in the treatment of COVID-19, antiinflammatory and anti-viral drugs are suggested [15, 16, 17] and polyphenols, a component in certain diets, especially herbs and spices used cuisine, have these properties $[18,19,20]$. Polyphenols have a role in 
combating the battle against COVID-19 [21, 22,23] and polyphenols are showed to disrupt spike proteins whereby reducing its attachment with ACE2 receptors in host cells [21,24,25].

Prior to the present pandemic, Matily Herbal Drink, a concoction made of ingredients rich in polyphenols like curry leaves (Murraya koenigii), mint leaves (Mentha sp) ginger, (Zingiber officinale), okra (Abelmoschus esculentus) and lemon (Citrus limon) with salt and sugar for taste, was designed and made to control hyperglycemia and hypercholesterolemia in patients who cannot afford pharmaceutical intervention because of poor economic conditions [26]. The study showed that the drink lowers hyperglycemia, hypercholesterolemia and oxidative stress [26]. It was also effective in treating shingles [27] suggesting its anti-viral activities.

Therefore, we suggested that Matily Herbal Drink could use as prophylactic and treatment for COVID-19 [ 1]. Later on, Matily Herbal Drink \& Spices Mix was developed for reducing complications associated with COVID-19 in the general population [28].

With above presentations in the background, we present the status of COVID-19 antibodies in a 65-year-old male who had natural infections a year ago and was on Matily Herbal Drink during the infection, followed by Matily Herbal \& Spices Mix, to avoid any complications in case of COVID19 reinfection.

\section{Case Study}

A 65-year-old male with a history of diabetes, global hypokinetic of Left Ventricle of heart (eff $<25 \%$ ) was infected with COVID-19 in early August 2020. On August 4th, the patient noticed throat pain and high body temperature after returning from his work in the evening. He kept his body temperature rising with a cold sponge on his forehead and feet to reduce multiplication of the virus inside the body.
The patient knew diabetic condition could aggravate corona infection. So the patient sipped Matily Herbal Drink throughout the night to control hyperglycemia. In the earlier studies, Matily Herbal Drink was shown to control hyperglycemia in the same patient [26]. After 18 hours from the detection of symptoms, his sister, a Registered Nurse working in Miami, Florida, informed that their patients are given Azithromycin $500 \mathrm{mg}$ and suggested taking the same under medical supervision. However, since the patient had low LV function, Azithromycin $250 \mathrm{mg}$ for 6 days been taken. The patient was on a regular vegetarian diet and he recovered completely after 7 days. The infection was confirmed with a qualitative assessment of the antibodies present in the blood (Table 1).

Corona infection caused fluid retention in the body and the patient could not sleep in the night from 12 midnight to till $4 \mathrm{am}$. The patient used to sit up during this time and slept from 4 am to 9 am. Later on, he was admitted to a hospital to treat fluid retention problems and was on diuretics and medicines for diabetes and hypertension. The patient recovered from all the complications and started his normal life slowly. During the review, the doctor advised him to discontinue his diabetic medicine, and he was only on Dytor $10 \mathrm{mg}$ and Telma $20 \mathrm{mg}$ with some multivitamin supplementation.

After the six months of recovery, the patient started taking half teaspoon of Matily Herbal \& Spices Mix powder once in a day along with little curd or buttermilk, as a blood thinner to avoid any complications associated with asymptomatic infection of COVID-19. The person moved around, doing his activities every day, following SMS (Sanitation, Mask and Social distancing) norms prescribed by health officials from the government.

In July 2021, the patient visited Kerala in India for some urgent work, where COVID-19 infections were rampant. He travelled to different places in Kerala on public transport 
and stayed in public places like hotels and lodges. The rapid antigen test and RT-PCR test were conducted prior to his interstate travels and found to be negative.

By the end of August 2021, after completing 12 months of post COVID-19 infections, qualitative assessment of antibody was carried out by Metropolis Labs, Mumbai [29]. The results were compared with the value got in September 2020, just after the recovery of COVID-19 infection (Table 1). Later on, a quantitative measurement of antibodies was carried out using Covid-protect test performed by Metropolis, Mumbai [29]. The tests were carried out on serum by Enzyme Chemiluminescence Immunoassay. (ECLIA).

\section{Results}

The status of antibodies against COVID-19 produced just after the recovery of the disease and after 12 months is given in Table 1 . The results got in the test carried out in September 2020 confirmed that the patient had Covid infection.

Table 1. Qualitative assessment of COVID-19 antibodies present in the patient just after the recovery of COVID-19 in September 2020 and after 12 months of post infection.

\begin{tabular}{|l|l|l|l|}
\hline Test & $\begin{array}{l}\text { Values obtained on } \\
19^{\text {th }} \text { September,2020 }\end{array}$ & $\begin{array}{l}\text { Values obtained on } \\
31^{\text {st }} \text { August,2021 }\end{array}$ & $\begin{array}{l}\text { Percentage of } \\
\text { difference in values }\end{array}$ \\
\hline $\begin{array}{l}\text { Qualitative assessment } \\
\text { of antibodies }\end{array}$ & 93 (Cut of Index) & 137 (Cut of Index) & $+47 \%$ \\
\hline
\end{tabular}

Table 1 shows the presence of antibodies against COVID-19 in the patient and there was an increase of antibodies (qualitatively) after 12 months..

The quantitative measurement of antibody titre present in the patient in August 2021 is shown in Table 2. The reported value was $1186 \mathrm{BAU} / \mathrm{ml}$. Since this test was not available in September 2020, the initial antibody titre could not be carried out.

We compared this result with the values got in two individuals who had taken both doses of vaccine and had completed two weeks after the final vaccination (Table 2).

Table 2: Quantitative assessment of antibody titres against COVID-19 virus, in the patient under case study and in the two individuals who had taken both doses of vaccine and completed two weeks.

\begin{tabular}{|l|l|}
\hline Quantitative assessment of antibodies in the case study subject & $1186 \mathrm{BAU} / \mathrm{ml}$ \\
\hline Quantitative assessment of antibodies in the case 1 subject & $13 \mathrm{BAU} / \mathrm{ml}$ \\
\hline Quantitative assessment of antibodies in the case 2 subject & $230 \mathrm{BAU} / \mathrm{ml}$ \\
\hline
\end{tabular}

Antibody titre of the two individuals who had both doses of vaccine and time period is 13 $\mathrm{BAU} / \mathrm{ml}$ and $230 \mathrm{BAU} / \mathrm{ml}$. The antibody titre of the patient under case study was 1186 BAU/ml. A general and informal survey of the values obtained in vaccinated people in the same locality was below $400 \mathrm{BAU} / \mathrm{ml}$. There was an increase of antibodies observed in the case study subject.

\section{Discussion}

The patho-physiology related to corona infection is discussed in our earlier reviews [3]. Virus enters through the nasal cavity and eyes, uses their spike proteins to attach with the ACE2 receptors in the host cells [30]. Once they enter the cell, they alter the physiology of the cell [31], to stimulate body temperature of the host $[32,33]$ 
In the present case study, the timely action taken to lower the body temperature with a cold sponge on the forehead and feet of the patient may have lowered virus load inside the body. Sipping Matily Herbal Drink may have lowered oxidative stress in the patient [26]. The speedy recovery of patients from shingles without taking Acyclovir $800 \mathrm{mg}$ tablets internally because of his poor heart condition, but was only on Matily Herbal Drink, supports the probability of antiviral properties of the drink [27]. The qualitative assessment of antibodies showed presence of antibodies

When any foreign organisms or toxins enter the body, antibody production is started inside the body. Thus, COVID-19 antibodies in the patient's blood show the previous infection

Antibody production is governed by diet, especially proteins and other factors. The patient in the case study had normal activities and ordinary vegetarian meals most of the time. Non-vegetarian items were poultry once in a month and six eggs in a month. Thus, the patient did not have any high protein diet or any protein supplements during the study period. It is also reported that antibodies in patients with post COVID-19 infection declines with time [34,35]. However, it is reported that antibodies last at least a year [36,37].

In the present case study, there was no decline in antibodies tested qualitatively, but on the contrary, increased from $93 \%$ to $136 \%$. The quantitative analysis of antibodies showed $1186 \mathrm{Au}$. We infer that the patient may have asymptomatic re-infection after recovering from the initial infections.

Recently, anti-viral and anti-inflammatory drugs have been recommended for treating COVID-19 [38]. Since polyphenols have antiviral and anti-inflammatory properties, they are suggested for the battle against Covid-19 $[39,40,41,43,43,44]$. Gupta et al. demonstrated that secondary metabolites from spices and herbs as potential multi target inhibitors of
SARS-CoV-2 proteins"[45]. Therefore, polyphenolic-based medications can mitigate SARS-CoV-2-enzymes, which are vital for virus duplication and infection" was suggested [46, 47].

The ingredients used in Matily Herbal Drink and Matily Herbal \& Spices Mix are rich in polyphenols with antioxidants and antiinflammatory properties. The properties of okra (Abelmoschus esculentus) [48,49, 50, 51] and lemon (Citrus limon) [52,53,54,55, 56. 57, 58] are discussed elsewhere.

The common ingredients in the Matily Herbal Drink and Matily Herbal \& Spices Mix were ginger, mint leaves and curry leaves.

Ginger is used traditionally in India. Its properties are discussed elsewhere [59, 60]. A recent study showed "the clinical effects of ginger on nausea and vomiting, gastrointestinal function, pain, inflammation, metabolic syndromes, and other symptoms. It was effective in a majority of studies, including those that examined the alleviation of nausea, vomiting in pregnancy (NVP), digestive function, improvement in the expression level of markers for colorectal cancer risk and antiinflammatory functions," [61].

Mint has antibacterial and antioxidant activities [62].

Curry leaves, Murraya koenigii, are used in Indian cuisine, are rich in polyphenols and have medicinal properties $[63,64,65]$. The analysis of various compounds by GC-MS is reported [66]. Its essential oil inhibited xanthine oxidase activity, which caused a decrease in the generation of superoxide radicals [66]. The antioxidant properties of Murraya koenigii leaf essential oil have scope for its use in food industry and medicine [63]. The flavonoids and polyphenols in the plant [66] and their anti-allergic, antioxidant, antiinflammatory, anti-viral and anti-cancer activities are discussed elsewhere [66]. 
In the present study, Matily Herbal Drink followed by Matily Herbal \& Spices Mix taken daily by the patient may have supplied polyphenols and the anti-viral and antiinflammatory properties of polyphenols may have inactivated the virus as explained above and helped the patient's immune system to combat COVID-19 infections. This may explain the relatively high antibody presence in the body compared with vaccinated individuals. The salicylates content in the mixture may have prevented micro blood clots in the body under asymptomatic infections

In the laboratories, the extraction of polyphenols from food is carried out with alcohol or other organic solvents and varies with extraction methods [67]. The bioavailability of polyphenols from the food is often debated. The bioavailability of polyphenols in the intestine depends on the matrix and it is low because of its hydrophobic nature. However, the bioavailability of polyphenols is increased with acidulants used in Indian cooking [68]. Lemon, tomatoes, tamarind, Malabar tamarind, armchur, curd and buttermilk are used to give sour taste to the food and are acidulants which facilitate increased bioavailability of polyphenols [69]. The micro biome in the intestine produces short-chain fatty acids (SCFA) that favours absorption of the polyphenols [70].

Matily Herbal Drink is prepared by grinding all the ingredients with a quantity of lime juice. This method gives better extraction and favours increased bioavailability of the polyphenols. The Drink gets slightly fermented if kept in the room temperature for 4 to 5 hours and fermentation may favour better bioavailability of polyphenols from the drink. Matily Herbal \& Spices Mix is advised to be taken with curd or buttermilk. The lactic acid in the curd and buttermilk may favour the bioavailability of polyphenols [71].

In the light of the present case study, we conclude that the Indian diet is rich in polyphenols [72,73] and the bioavailability of polyphenols Indian cooking increases with the use of acidulants [68]. The increased bioavailability of polyphenols along with salicylates in the Indian diet [3] may have contributed to the survival of COVID-19 patients. The bioavailability of polyphenols from Matily Herbal Drink and Matily Herbal \& Spices Mix may have increased because of the presence of acidulants. Polyphenols inactivate the virus, as explained earlier, leading to increased antibody production in the body.

The International agencies are aiming to develop methods to boost antibodies with various vaccines and booster doses. The present study throws some light that a single or double dose of vaccine along with a polyphenol rich diet like Matily Herbal \& Spices Mix or even a proper Indian vegetarian diet with acidulated may boost antibody production in the population to combat the present pandemic. Quantification of antibody titre may be a better criterion to confirm the health status of an individual instead of just vaccinations.

\section{Conclusion}

We conclude polyphenols have a role in combating COVID-19 and the bioavailability of polyphenols depends on various factors, including acidulants, in the diet. In this context, the Matily Herbal Drink and Matily Herbal \& Spices Mix with acidulants may boost bioavailability of polyphenols. India should develop her own strategy to increase antibodies in the population instead of just following the norms laid by International Agencies, which are under the influence of pharmaceutical companies.

\section{Acknowledgement S}

The author appreciates the role of Dr. M.S. Valiathan and Sree Chitra Tirunal Institute of Medical Sciences \& Technology (SCTIMST), Thiruvananthapuram, initiating him biomedical research. 
The author named the drink as Matily in remembrance of his father, Mr M.E. Eapen (1926-2018), known among his American friends as "MAT" and who continuously encouraged the author to innovate methods to ease the suffering of the afflicted.

\section{References}

1. Eapen J T. Matily herbal drink could be a prophylaxis and therapy against COVID19: a possibility. Int J Res Med Sci 2021; Sep 9(2): 651-654. doi:http://dx.doi.org/10.18203/23206012.ijrms20210461

2. Hiscott J, Alexandridi M, Muscolini M, Tassone E, Palermo E, Soultsioti M, Zevini A. The global impact of the coronavirus pandemic. Cytokine Growth Factor Rev. $2020 \quad$ Jun;53:1-9. doi: 10.1016/j.cytogfr.2020.05.010. Epub 2020 May 28. PMID: 32487439; PMCID: PMC7254014.

3. Eapen, JT. Let food be thy medicine Could Indian Diet contribute to the Survival Rate of COVID19 patients in India? International Journal Dental and Medical Sciences Research (IJDMSR). 2021, MarApr 3(2), 568374.https://doi.org/10.35629/52520302568574

4. Abou-Ismail MY, Diamond A, Kapoor S, Arafah Y, Nayak L. The hypercoagulable state in COVID-19: Incidence, pathophysiology, and management. Thromb Res. 2020 Oct;194:101-115. doi: 10.1016/j.thromres.2020.06.029. Epub 2020 Jun 20. Erratum in: Thromb Res. 2020 Nov 26;: PMID: 32788101; PMCID: PMC7305763.

5. Loo J, Spittle DA, Newnham M. COVID19 , immunothrombosis and venous thromboembolism: biological mechanisms. Thorax. 2021 Apr;76(4):412420. doi: 10.1136/thoraxjnl-2020-216243. Epub 2021 Jan 6. PMID:33408195.
6. Attaway $\mathrm{AH}$, Scheraga RG, Bhimraj A, Biehl M, Hatipoğlu U. Severe covid-19 pneumonia: pathogenesis and clinical management. BMJ. 2021 Mar 10;372:n436. doi: 10.1136/bmj.n436. PMID:33692022.

7. Bianconi V, Violi F, Fallarino F, Pignatell i P, Sahebkar A, Pirro M. Is Acetylsalicylic Acid a Safe and Potentially Useful Choice for Adult Patients with COVID-19? Drugs. 2020 Sep;80(14):1383-1396. doi: 10.1007/s40265-020-01365-1. PMID

8. Rizk JG, Lavie CJ, Gupta A. Low-dose aspirin for early COVID-19: does the early bird catch the worm? Expert Opin Investig Drugs. 2021 Aug;30(8):785-788. doi: $\quad 10.1080 / 13543784.2021 .1950687$. Epub 2021 Jul 12. PMID: 34190669.

9. Chow, Jonathan H. MD; Khanna, Ashish K. MD2,3; Kethireddy, Shravan MD4; Yamane, David MD5; Levine, Andrea MD6; Jackson, Amanda M. MD, MAJ, MC, USA7; McCurdy, Michael T. MD7; Tabatabai, Ali MD6,8; Kumar, Gagan MD4; Park, Paul MD9; Benjenk, Ivy RN, MPH.10; Menaker, Jay MD8,11; Ahmed, Nayab MD12; Glidewell, Evan MD13; Presutto, Elizabeth MD9; Cain, Shannon M.D.14; Haridasa, Naeha B.S10; Field, Wesley MD12; Fowler, Jacob G. B.S.13; Trinh, Duy MD9; Johnson, Kathleen N. B.S.13; Kaur, Aman DO12; Lee, Amanda B.S.9; Sebastian, Kyle MD13; Ulrich, Allison MD9; Peña, Salvador MD, PhD13; Carpenter, Ross MD9; Sudhakar, Shruti MD9; Uppal, Pushpinder MD9; Fedeles, Benjamin T. MD, Capt., USAF, MC9; Sachs, Aaron MD9; Dahbour, Layth MD9; Teeter, William

MD8,15; Tanaka, Kenichi MD16; Galvagno, Samuel M. DO, PhD1,8; Herr, Daniel L. MD7; Scalea, Thomas M. MD8,11; Mazzeffi, Michael A. MD, MPH1,16 Aspirin Use is Associated with 
Decreased Mechanical Ventilation, ICU Admission, and In-Hospital Mortality in Hospitalized Patients with COVID-19, Anesthesia \& Analgesia: October 21, 2020 - Volume Publish Ahead of Print - Issue doi:10.1213/ANE.0000000000005292

10. Haque S, Jawed A, Akhter N, Dar SA, Khan F, Mandal RK, Areeshi MY, Lohani M, Wahid M. Acetylsalicylic acid (Aspirin): a potent medicine for preventing COVID-19 deaths caused by thrombosis and pulmonary embolism. Eur Rev Med Pharmacol Sci. 2020 Sep;24(18):92449245. doi: 10.26355/eurrev_202009_23005. PMID:33015764.

11. Lévesque $\mathrm{H}$, Lafont $\mathrm{O}$. L'aspirine à travers les siècles: rappel historique [Aspirin throughout the ages: a historical review]. Rev Med Interne. 2000 Mar;21 Suppl 1:8s17s. French. doi: 10.1016/s02488663(00)88720-2. PMID: 10763200.

12. Duthie GG, Wood AD. Natural salicylates: foods, functions and disease prevention. Food Funct. 2011 Sep;2(9):515-20. doi: 10.1039/c1fo10128e. Epub 2011 Aug 30. PMID: 21879102.

13. Gajewska D, Kęszycka PK, Sandzewicz M, Kozłowski P, Myszkowska-Ryciak J. Intake of Dietary Salicylates from Herbs and Spices among Adult Polish Omnivores and Vegans. Nutrients. $2020 \quad$ Sep 6;12(9):2727. doi: 10.3390/nu12092727. PMID: 32900002; PMCID: PMC7551261.

14. Paterson JR, Srivastava R, Baxter GJ, Graham AB, Lawrence JR. Salicylic acid content of spices and its implications. J Agric Food Chem. 2006 Apr 19;54(8):2891-6. doi: 10.1021/jf058158w. PMID:16608205.

15. Stebbing J, Phelan A, Griffin I, Tucker C, Oechsle O, Smith D, Richardson P. COVID-19: combining antiviral and anti-inflammatory treatments. Lancet Infect Dis. 2020 Apr;20(4):400402. doi: 10.1016/S1473-3099(20)30132-
8. Epub 2020 Feb 27. PMID: 32113509; PMCID:PMC7158903.

16. Darvishalipour, S. (2020). COVID-19: combining antiviral and anti-inflammatory treatments. Iranian Journal of Biology, 4(7), 282-285.

17. Purwati, Miatmoko A, Nasronudin, Hendrianto E, Karsari D, Dinaryanti A, Ertanti N, Ihsan IS, Purnama DS, Asmarawati TP, Marfiani

E, Yulistiani, Rosyid AN, Wulaningrum PA, Setiawan HW, Siswanto

I, Tri Puspaningsih NN. An in vitro study of dual drug combinations of anti-viral agents, antibiotics, and/or hydroxychloroquine against the SARSCoV-2 virus isolated from hospitalized patients in Surabaya, Indonesia. PLoS One. 2021 Jun 18;16(6):e0252302. doi: 10.1371/journal.pone.0252302. PMID: 34143818 ; PMCID: PMC8213153.

18. Opara EI, Chohan M. Culinary herbs and spices: their bioactive properties, the contribution of polyphenols and the challenges in deducing their true health benefits. Int J Mol Sci. 2014 Oct 22;15(10):19183-202. doi: 10.3390/ijms151019183. PMID: 2534098 2; PMCID: PMC4227268.

19. Utkarsh Ghate and Hema Kulkarni (June 24th 2021). Polyphenols, Spices and Vegetarian Diet for Immunity and Anti-Inflammatory Drug Design [Online First], IntechOpen, DOI: 10.5772/intechopen.97661.Available from: https:/www.intechopen.com/onlinefirst $/ 76748$

20. Yashin A, Yashin Y, Xia X, Nemzer B. Antioxidant Activity of Spices and Their Impact on Human Health: A Review. Antioxidants (Basel). 2017 Sep 15;6(3):70. doi: 10.3390/antiox6030070. PMID: 28914764; PMCID: PMC5618098.

21. Paraiso IL, Revel JS, Stevens JF. Potential use of polyphenols in the battle against COVID-19. Curr Opin Food Sci. 2020 
Apr;32:149-155.

doi: 10.1016/j.cofs.2020.08.004. Epub 2020 Sep 9. PMID: 32923374; PMCID: PMC7480644.

22. Annunziata G, Sanduzzi Zamparelli M, Santoro C, Ciampaglia R, Stornaiuolo M, Tenore GC, Sanduzzi A and Novellino E (2020) May Polyphenols Have a Role Against Coronavirus Infection? An Overview of in vitro Evidence. Front. Med. 7:240.

doi:

10.3389/fmed.2020.00240

23. El-Missiry MA, Fekri A, Kesar LA, Othman AI. Polyphenols are potential nutritional adjuvants for targeting COVID19. Phytother Res. 2021 Jun;35(6):28792889. doi: 10.1002/ptr.6992. Epub 2020 Dec 22. PMID:33354848.

24. Goc A, Sumera W, Rath M, Niedzwiecki A. Phenolic compounds disrupt spikemediated receptor-binding and entry of SARS-CoV-2 pseudo-virions. PLoS One. 2021 Jun 17;16(6):e0253489. doi: 10.1371/journal.pone.0253489. PMID: 34138966; PMCID: PMC8211150.

25. Eapen JT. Matily Herbal Drink May Reduce Oxidative Stress, Hyperglycemia, and Hyperlipidemia and Increases Immunity - Case Study Reports. Global Journal of Medical

Research,[S.1.],aug.2020.ISSN22494618. Availableat:

$<$ https://medicalresearchjournal.org/index. php/GJMR/article/view/2189>. Date accessed: 16 sep. 2021.37

26. Eapen JT. Managing Shingles (HZ) in Elderly with Topical Application of Acyclovir $5 \mathrm{mg}$ and Increasing Immunity with Matily Herbal Drink - A Case Study. Global Journal of Medical Research,[S.1.],aug.2020.ISSN22494618. Availableat: $<$ https://medicalresearch journal.org/index.php/GJMR/article/view/ 2192>. Date accessed: 16 sep. 2021.

27. Eapen JT. Including matily herbal and spices mix in Indian diet may reduce complications of COVID-19 infection in the general population. Int J Res Med Sci 2021;9:2816-20.

28. https://www.metropolisindia.com/coviprot ect-test

29. Luan J, Lu Y, Jin X, Zhang L. Spike protein recognition of mammalian ACE2 predicts the host range and an optimized ACE2 for SARS-CoV2 infection. Biochem Biophys Res Commun. 2020 May 21;526(1):165-169. doi: 10.1016/j.bbrc.2020.03.047. Epub 2020 Mar 19. PMID: 32201080; PMCID: PMC7102515.

30. Gul MH, Htun ZM, Inayat A. Role of fever and ambient temperature in COVID-19. Expert Rev Respir Med. 2021 Feb;15(2):171-173. doi: 10.1080/17476348.2020.1816172. Epub 2020 Sep 9. PMID: 32901576; PMCID: PMC7544962.Grant MC, Geoghegan L, Arbyn M, Mohammed Z

31., McGuinness L, Clarke EL, Wade RG. The prevalence of symptoms in 24,410 adults infected by the novel coronavirus (SARS-CoV-2; COVID-19): A systematic review and meta-analysis of 148 studiesfrom 9 countries. PLoS One. 2020 Jun 23;15(6):e0234765. doi: 10.1371/journal.pone.0234765. PMID: 32574165; PMCID: PMC7310678.

32. Blaess M, Kaiser L, Sauer M, Csuk R, Deigner HP. COVID-19/SARS-CoV-

2Infection: Lysosomes and Lysosomotropism Implicate New Treatment Strategies and Personal Risks. Int J Mol Sci. 2020 Jul 13;21(14):4953. doi: $10.3390 /$ ijms21144953. PMID: 32668803; PMCID: PMC7404102.

33. Beaudoin-Bussières G, Laumaea A, Anand SP, Prévost J, Gasser R, Goyette G, Medjahed H, Perreault J, Tremblay T, Lewin A, Gokool L, Morrisseau C, Bégin P, Tremblay C, Martel-Laferrière V, Kaufmann DE, Richard J, Bazin R, Finzi A. Decline of 
Humoral Responses against SARS-CoV2 Spike in Convalescent Individuals. mBio. 2020 Oct 16;11(5):e02590-20. doi: 10.1128/mBio.02590-20. PMID: 33067385; PMCID: PMC7569150.

34. Chen Y, Tong X, Li Y, Gu B, Yan J, Liu Y, Shen H, Huang R, Wu C. A comprehensive, longitudinal analysis of humoral responses specific to four recombinant antigens of SARS-CoV-2 in severe and non-severe COVID-19 patients. PLoS 2020 Sep 10;16(9):e1008796. doi: 10.1371/journal.ppat.1008796. PMID: 32913364; PMCID: PMC7482996.

35. Anand SP, Prévost J, Nayrac M, BeaudoinBussières G, Benlarbi M, Gasser R, Brassard N, Laumaea A, Gong SY, Bourassa C, BrunetRatnasingham E, Medjahed H, GendronLepage G, Goyette G, Gokool L, Morrisseau C, Bégin P, MartelLaferrière V, Tremblay C, Richard J, Bazin R, Duerr R, Kaufmann DE, Finzi A. Longitudinal analysis of humoral immunity against SARS-CoV-

2 Spike in convalescent individuals up to 8 months post-symptom onset. Cell Rep Med. 2021 Jun 15;2(6):100290. doi:10.1016/j.xcrm.2021. 100290. Epub 2021 May 5. PMID: 33969322; PMCID: PMC8097665.

36. Dobaño C, Ramírez-Morros A, Alonso $S$, Vidal-Alaball J, Ruiz-Olalla G, Vidal M, Rubio R, Cascant E, Parras D, Rodrigo Melero N, Serra P, Carolis C, Santamaria P, Forcada A, Mendioroz J, Aguilar R, Moncunill G, Ruiz-Comellas A. Persistence and baseline determinants of seropositivity and reinfection rates in health care workersup to 12.5 months after COVID-19. BMC Med. 2021 Jun 28;19(1):155. doi: 10.1186/s12916-02102032-2. PMID: 34183003; PMCID: PMC8237770.।
37. Paraiso IL, Revel JS, Stevens JF. Potential use of polyphenols in the battle against COVID-19. Curr Opin Food Sci. 2020 Apr;32:149-155. doi: 10.1016/j.cofs.2020.08.004. Epub 2020 Sep 9. PMID: 32923374; PMCID: PMC7480644.

38. Levy E, Delvin E, Marcil V, Spahis S. Can phytotherapy with polyphenols serve as a powerful approach for the prevention and therapy tool of novel coronavirus disease 2019 (COVID-19)? Am J Physiol Endocrinol Metab. 2020 Oct 1;319(4):E689-E708. doi: 10.1152/ajpendo.00298.2020. Epub 2020 Aug 5.5 PMID: 32755302; PMCID: PMC7518070.

39. Math MV, Kattimani YR, Gadda RB, Khadkikar RM. Plant products in reducing spread of coronavirus infection (COVID19). $\mathrm{Br} J$ Oral Maxillofac Surg. 2021 May;59(4):497-498. doi: 10.1016/j.bjoms.2020.11.005. Epub 2020 Nov 17. PMID: 33685770; PMCID: PMC7670260.

40. Taha Mehany, Ibrahim Khalifa, Hassan Barakat, Sami A. Althwab, Yousef M. Alharbi, Sobhy El-Sohaimy, Polyphenols as promising biologically active substances for preventing SARS-CoV-2: A review with research evidence and underlying mechanisms,

$\begin{array}{lrr}\text { Food } & \text { Bioscience, } & \text { Volu } \\ \text { me } & \text { 40,2021,100891,ISSN } & 2 \\ \text { 212- } & \\ \text { 4292, https://doi.org/10.1016/j.fbio.2021.1 } \\ \text { 00891. }\end{array}$

41. Annunziata G, Sanduzzi Zamparelli M, Santoro C, Ciampaglia R, Stornaiuolo M, Tenore GC, Sanduzzi A, Novellino E. May Polyphenols Have a Role Against Coronavirus Infection? An Overview of in vitro Evidence. Front Med (Lausanne). 2020 May 15;7:240. doi: 10.3389/fmed.2020.00240. PMID: 32574331 ; PMCID: PMC7243156. 
42. Laguipo, Angela. "Polyphenols may provide protective effect against COVID19

Medical. 12 September

www.news-

$$
\text { 2021.<https:// }
$$

medical.net/news/20210222/Polyphenolsmay-provide-protective-ef fect-againstCOVID-19-disease.aspx>.

43. Volkan Gelen, Abdulsamed Kükürt, Emin Şengül, Ömer Faruk Başer and Mahmut Karapehlivan (August 9th 2021). Can Polyphenols be Used as Anti-Inflammatory Agents againstCovid-19(SARS-CoV-2)InducedInflammation?

[Online First], IntechOpen, DOI:10.5772/ intechopen.98684. Available from: https:// www.intechopen.com/online-first/77746

44. Chojnacka K, Witek-Krowiak A, Skrzypczak D, Mikula K, Młynarz P. Phytochemicals containing biologically active polyphenols as an effective agent against Covid-19-inducing coronavirus. Journal of Functional Foods, Volume 73, 2020, 104146, https://doi.org/10.1016/j.jff. 2020.104146.

45. Gupta S, Singh V, Varadwaj PK, Chakravartty N, Katta AVSKM, Lekkala SP, Thomas G, Narasimhan S, Reddy AR, Reddy Lachagari VB. Secondary metabolites from spice and herbs as potential multitarget inhibitors of SARS-CoV-2 proteins. J Biomol Struct Dyn. 2020 Oct 27:1-20. doi: 10.1080/07391102.2020.1837679. Epub ahead of print. PMID: 33107812; PMCID: PMC7605658.

46. Goc A, Sumera W, Rath M, Niedzwiecki A (2021) Phenolic compounds disrupt spikemediated receptor-binding and entry of SARS-CoV-2 pseudo-virions.

PLoS ONE 16(6): e0253489.https://doi.org/10.1371/journal. pone.0253489
47. Basu, A., Sarkar, A. \& Maulik, U. Molecular docking study of potential phytochemicals and their effects on the complex of SARS-CoV2 spike protein and human ACE2. Sci Rep 10, 17699 (2020).https://doi.org/10.1038/s41598020-74715-4

48. Xia F, Zhong Y, Li M, Chang Q, Liao Y, Liu X, Pan R. Antioxidant and Anti-Fatigue Constituents of Okra. Nutrients. 2015 Oct 26;7(10):8846-58. doi: 10.3390/nu7105435. PMID: 26516905; PMCID: PMC4632455.

49. Peter EL, Nagendrappa PB, Ajayi CO, Sesaazi CD (2021) Totalpolyphenols and antihyperglycemic activity of aqueous fruits extract of Abelmoschusesculentus: Modeling and optimization of extraction conditions. PLoS ONE 16(4): e0250405. https://doi.org/10.1371/journal.pone.0250 405

50. Dantas TL, Alonso Buriti FC, Florentino ER. Okra (Abelmoschus esculentus L.) as a Potential Functional Food Source of Mucilage and Bioactive Compounds withTechnological Applications and Health Benefits. Plants (Basel). 2021 Aug 16;10(8):1683. doi: 10.3390/plants10081683. PMID: 34451728; PMCID: PMC8399980.

51. Dantas TL, Alonso Buriti FC, Florentino ER. Okra (Abelmoschus esculentus L.) as a Potential Functional Food Source of Mucilage and Bioactive Compounds withTechnological Applications and Health Benefits. Plants (Basel). 2021 Aug 16;10(8):1683. doi: 10.3390/plants10081683. PMID: 34451728; PMCID: PMC8399980.

52. Shimizu, C., Wakita, Y., Inoue, T. et al. Effects of lifelong intake of lemon polyphenols on aging and intestinal microbiome in the senescence-accelerated mouse prone 1 (SAMP1). Sci Rep 9, 3671 (2019).https://doi.org/10.1038/s41598019-40253-x 
53. Xi W, Lu J, Qun J, Jiao B. Characterization of phenolic profile and antioxidant capacity of different fruit part from lemon (Citrus limon Burm.) cultivars. J Food Sci Technol. 2017 Apr;54(5):1108-1118. doi: 10.1007/s13197-017-2544-5. Epub 2017 Feb 25. PMID: 28416860; PMCID: PMC5380627.

54. Pontifex MG, Malik MMAH, Connell E, Müller $\quad M \quad$ and Vauzour D (2021) Citrus Polyphenols in Brain He alth and Disease: Current Perspective s. Front. Neurosci. 15:640648. doi:10.3389/fnins.2021.640648

55. Shimizu, C., Wakita, Y., Inoue, T. et al. Effects of lifelong intake of lemon polyphenols on aging and intestinal microbiome in the senescence-accelerated mouse prone 1 (SAMP1). Sci Rep 9, 3671 (2019).https://doi.org/10.1038/s41598019-40253-x

56. Xi W, Lu J, Qun J, Jiao B. Characterization of phenolic profile and antioxidant capacity of different fruit part from lemon (Citrus limon Burm.) cultivars. J Food Sci Technol. 2017 Apr;54(5):1108-1118. doi: 10.1007/s13197-017-2544-5. Epub 2017 Feb 25. PMID: 28416860; PMCID: PMC5380627.

57. Pontifex MG, Malik MMAH, Connell E, Müller $M$ and Vauzour D (2021) Citrus Polyphenols in Brain He alth and Disease: Current Perspective s. Front. Neurosci. 15:640648. doi:10.3389/fnins.2021.640648

58. Muscatello MRA,Zoccali RA, Bruno A, Chapter 11 - Citrus Fruit Polyphenols and Flavonoids: Applications to Psychiatric Disorders, $\quad$ Editor(s): Ronald Ross Watson, Victor R. Preedy, Sherma Zibadi, Polyphenols: Mechanisms of Action in Human Health and Disease (Second Edition), Academic Press, 2018,Pages 119-

131, https://doi.org/10.1016/B978-0-12813006-3.00011-8.
59. Mao

QQ,

$\mathrm{Xu} X Y$, Cao SY, Gan RY, Corke H, Beta T, Li HB. Bioactive Compounds and Bioactivities of Ginger (Zingiber officinale Roscoe). Foods. 2019 May

30;8(6):185. doi: 10.3390/foods 8060185 . PMID: 31151279 ; PMCID:PMC3466165

60. Ali AMA, El-Nour MEM, Sakina Mohamed Yagi SM. Total phenolic and flavonoid contents and antioxidant activity of ginger (Zingiber officinale Rosc.) rhizome, callus and callus treated with some elicitors. Journal of Genetic Engineering and Biotechnology, 2018, 16:(2),677-

682.https://doi.org/10.1016/j.jgeb.2018.03 .003 .

61. Anh NH, Kim SJ, Long NP, Min JE, Yoon YC, Lee EG, Kim M, Kim TJ, Yang YY, Son EY, Yoon SJ, Diem NC, Kim HM, Kwon SW. Ginger on Human Health: A Comprehensive Systematic Review of 109 Randomized Controlled Trials. Nutrients. 2020 Jan 6;12(1):157. doi: 10.3390/nu12010157. PMID: 31935866; PMCID: PMC7019938

62. Singh R, Muftah A.M. Shushni, Asma Belkheir, Antibacterial and antioxidant activities of Mentha piperita L. Arabian Journal of Chemistry,2015, 8(3):322-328. https://doi.org/10.1016/j.arabjc.2011.01.01 9.

63. Balakrishnan R, Vijayraja D, Jo SH, Ganesan P, Su-Kim I, Choi DK. Medicinal Profile, Phytochemistry, and Pharmacological Activities of Murraya koenigii and its Primary Bioactive Compounds. Antioxidants (Basel). 2020 Jan 24;9(2):101. doi: 10.3390/antiox9020101. PMID: 31991665; PMCID: PMC7070712.

64. Bhandari PR. Curry leaf (Murraya koenigii) or Cure leaf: Review of its curative properties. J Med Nutr Nutraceut 2012;1:92-7 
65. Patterson J, Verghese M. Anticancer and Toxic Effects of Curry Leaf (Murraya koenigii) Extracts. Journal of Pharmacology and Toxicology, 2015, 10: 49-59. DOI: $10.3923 /$ jpt.2015.49.59

66. Rajendran MP, Pallaiyan BB, Selvaraj N. Chemical composition, antibacterial and antioxidant profile of essential oil from Murraya koenigii (L.) leaves. Avicenna J Phytomed. 2014 May;4(3):200-14. PMID: 25050318; PMCID: PMC4104627

67. Parithy MT, Mohd Zin Z, Hasmadi M, Rusli ND, Smedley KL, Zainol MK. Antioxidants properties of Murraya koenigii: a comparative study of three different extraction methods. Food Research2021 Feb 5 (1) : 43 - 49. Accessed from https://www.myfoodresearch.com/uploads /8/4/8/5/84855864/ 5 fr-2020-

307 parithy.pdf on 21 September,2021.

68. Hithamani G, Srinivasan K. Bioaccessibility of polyphenols from selected cereal grains and legumes as influenced by food acidulants. J Sci Food Agric. 2017 Jan;97(2):621-628. doi: 10.1002/jsfa.7776. Epub 2016 Jun 2. PMID: 27122477.

69. Hemalatha S, Patel K, Srinivasan K. Influence of food acidulants on bioaccessibility of zinc and iron from selected food grains. Mol Nutr Food Res. 2005 Oct;49(10):950-6. doi: 10.1002/mnfr.200500068. PMID: 16189798.

70. Kawabata K, Yoshioka Y, Terao J. Role of Intestinal Microbiota in the Bioavailability and Physiological Functions of Dietary Polyphenols. Molecules. 2019 Jan 21;24(2):370. doi: 10.3390/molecules24020370. PMID: 30669635 ; PMCID: PMC6359708.

71. Zhao D, Shah NP. Concomitant ingestion of lactic acid bacteria and black tea synergistically enhances flavonoid bioavailability and attenuates d-galactoseinduced oxidative stress in mice via modulating glutathione antioxidant system. J Nutr Biochem. 2016 Dec;38:116-124. doi: 10.1016/j.jnutbio.2016.09.005. Epub 2016 Sep 18. PMID: 27736731.

72. Nair S, Nagar R, Gupta R. Antioxidant phenolics and flavonoids in common Indian foods. J Assoc Physicians India. 1998 Aug;46(8):708-10. PMID: 11229280

73. Panche, A, Diwan A, Chandra S. Flavonoids: An overview. Journal of Nutritional Science, 2016, 5:E47. Doi:10.1017/jns.2016.41 